\title{
Use of FT-NIR Spectroscopy for Bovine Colostrum Analysis
}

\author{
P. NAVRÁTILOVÁ ${ }^{1}$, L. HADRA ${ }^{1}$, M. DRAČKOVÁ ${ }^{1}$, B. JANŠTOVÁ ${ }^{1}$, L. VORLOVÁ $^{1}$, L. PAVLATA $^{2}$ \\ ${ }^{1}$ Department of Milk Hygiene and Technology, Faculty of Veterinary Hygiene and Ecology, \\ ${ }^{2}$ Clinic of Ruminant Diseases, Faculty of Veterinary Medicine, \\ University of Veterinary and Pharmaceutical Sciences Brno
}

Received July 8, 2005

Accepted March 16, 2006

\begin{abstract}
Navrátilová P., L. Hadra, M. Dračková, B. Janštová, L. Vorlová, L. Pavlata: Use of FT-NIR spectroscopy for bovine colostrum analysis. Acta Vet. Brno 2006, 75: 57-63.

Fourier transformation near infrared spectroscopy (FT-NIR) in combination with partial least squares (PLS) method were used to determine the content of total solids, fat, non-fatty solids, lactose and proteins in bovine colostrum. Spectra of 90 samples were measured in the reflectance mode with a transflectance cuvette in the $10000-4000 \mathrm{~cm}^{-1}$ spectral ranges with 100 scans. Calibration was performed and statistical values of correlation coefficients (R) and standard error of calibration values (SEC) were computed for total solids (0.986 and 0.919 , respectively), fat ( 0.997 and 0.285 , respectively), non-fatty solids ( 0.995 and 0.451 , respectively), lactose $(0.934$ and 0.285 , respectively) and protein ( 0.999 and 0.149 , respectively). The calibration models developed were verified by cross validation. It follows from the study that FT-NIR spectroscopy can be used to determine the components of bovine colostrum.
\end{abstract}

Colostrum, near-infrared, fat, non-fatty solids, total solids, lactose, protein

Colostrum is the first mammary secretion after parturition. It is essential for nutrition, growth and development of the newborn. The composition of bovine colostrum is different from that of mature milk. It is not only a rich source of nutrients (proteins, carbohydrates, lipids, vitamins and minerals) but first and foremost it is a unique source of bioactive components. Some of the most important bioactive components are growth and antimicrobial factors. In the young, growth factors in the colostrum stimulate the growth and differentiation of various types of cells, and in adult individuals they help regenerate cells damaged by injury or disease and slow down the processes connected with ageing. Antimicrobial factors of colostrum provide passive immunity; they are indispensable for the development and regulation of the immune system; and they directly participate in defence responses against microorganisms (Pakkanen and Aalto 1997).

When colostrum is processed for dairy products, its different composition, sensorial, physical and chemical properties cause problems. In most countries, colostrum is therefore excluded from bulk milk collection for treatment and processing in dairies for 5 days post partum (Marnila and Korhonen 2003).

In many countries, bovine colostrum and its specific components are commercially available as food supplements or colostrum substitutes for farm animals. They are given to newborn calves and piglets as prevention from some diarrhoeal diseases. Preparations made from the colostrum of hyper-immunized cows for the prevention from specific gastrointestinal diseases are now being introduced to both human and veterinary medicine. As more is known about its composition and biological effects, bovine colostrum is reasserting its position of a popular natural substance that humans can use as a supplement and for the treatment and prevention of a number of health problems. Colostrum-based preparations are recommended as supplements for sportsmen, or as products boosting the human immune system. There are over 4000 clinical studies from all over the world that

Address for correspondence:

MVDr. Pavlína Navrátilová, Ph.D

Department of Milk Hygiene and Technology

University of Veterinary and Pharmaceutical Sciences

Palackého 1/3, 61242 Brno, Czech Republic
Phone: +420541562716

Fax: +420 541562711

E-mail: navratilovap@vfu.cz

http://www.vfu.cz/acta-vet/actavet.htm 
describe the use of colostrum for the treatment of a large number of various diseases. Besides its pharmaceutical and food industry applications, colostrum and its specific components are used e.g. in biotechnologies (growth media for culturing cells) and in the cosmetics industry (Pakkanen and Aalto 1997; Marnila and Korhonen 2003; Alexieva et al. 2004).

Food industry and agriculture are the only sectors where NIR spectroscopy has been used since the 1960s (determination of moisture, protein, oils and fats, saccharides). It has also been successfully used in pharmacy, petrochemistry, medicine and the environment monitoring. NIR spectroscopy is most frequently used for the determination of principal components, i.e. solids, proteins, fat and saccharides. The scope of NIR spectroscopy is, however, much wider and also includes the determination of sensorial, physical and chemical parameters (density, freezing point, $\mathrm{pH}$, particle size). The success of NIR spectroscopy depends not only on the quality of the spectroscope and its design, but also on the reference method, standardized preparation of samples, their homogeneity and the calibration method (Čurda et al. 2002; Rodríguez-Otero et al. 1997a; Tsenkova et al. 1999).

NIR spectroscopy offers a number of advantages over traditional chemical methods. It is a physical, non-destructive method, with minimum or no need for sample preparation. It saves time, labour and material, it is easy to use and can also be used for samples in transparent wrappings. One spectrum can be used for a quantitative analysis of several components, but also for a qualitative analysis (Büning-Pfaue 2003; Šustová and Jankovská 2002).

While middle infrared spectroscopy (MIR) absorptions are based on the first harmonic vibrations of chemical bonds in molecules, in the NIR range, combination oscillations and overtones of those vibrations are registered. Absorptions in the NIR range are therefore lower, and they make it possible to analyze more concentrated and thicker samples than it is possible in MIR spectroscopy (Is engard 2001; Rodríguez-Otero et al. 1997a).

The different composition, physical and chemical properties of colostrum rule out the use of raw milk calibration models, which are not calibrated for the range of values that are encountered in colostrum. The aim of the present work therefore was to develop calibration models for the determination of total solids, fat, non-fatty solids, protein and lactose in bovine colostrum using FT-NIR.

\section{Materials and Methods}

A total of 90 samples of colostrum were collected. The samples were collected from 18 dairy cows at 24-hour intervals over $5-6$ days.

Using reference methods, fat (ČSN 570530, 1995), total solids (ČSN ISO 6731, 1997), non-fatty solids (difference between total solids and fat), lactose and proteins (ČSN 570536, 1999) were determined in the samples.

Milk samples were tested using Nicolet Antaris Near-IR Analyzer spectrometer (Thermo Electron Corporation, Madison, USA) in the spectral range of $10000-4000 \mathrm{~cm}^{-1}$, and a hundred scans were made. The scanning time of one spectrum was about $1.5 \mathrm{~min}$. The spectra were measured on the integration sphere in the reflectance mode using transflectance cuvettes with optical thickness of $0.1 \mathrm{~mm}$. The samples were heated to $40{ }^{\circ} \mathrm{C}$, mixed, cooled to $20{ }^{\circ} \mathrm{C}$ and transferred to Petri dishes. The data obtained were processed by TQ Analyst software, version 6.2.1.509, using the partial least squares (PLS) method. The same samples were used for cross-validation.

For statistical evaluation, statistical and graphic software STAT Plus, VÚVeL Brno (Matoušková et al. 1992) was used.

\section{Results and Discussion}

Ninety samples were used to develop the total solids calibration model and 65 samples to develop the calibration model for fat, non-fatty solids, lactose and proteins. Samples in which a deviation in the measured spectrum was found (Fig. 1) or the determination of the reference value was inaccurate were excluded using a diagnostic tool Spectrum Outlier and Leverage ( 3 for total solids, 0 for fat and lactose, 1 for non-fatty solids and 6 for protein). 


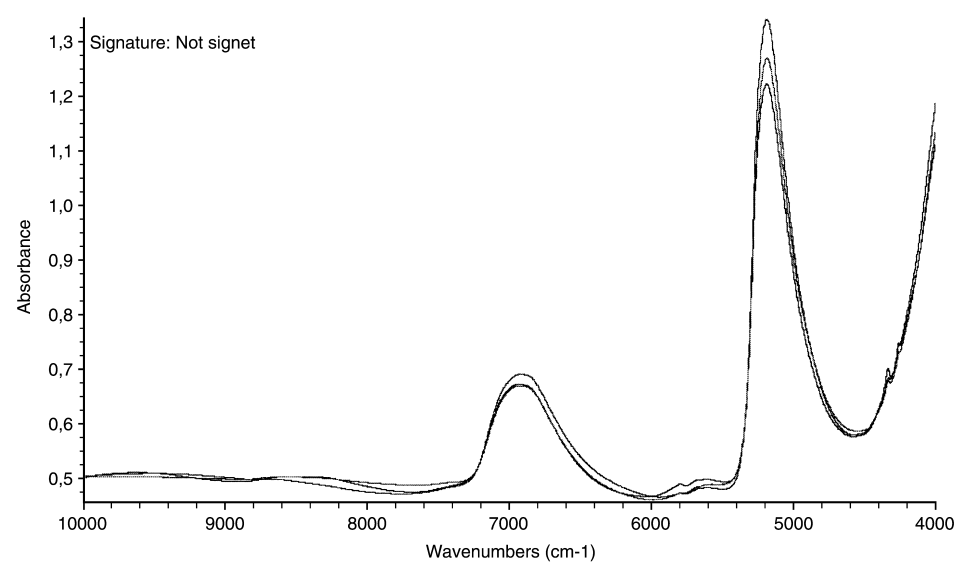

Fig. 1. Colostrum spectra

Calibration models were developed using the PLS algorithm. PLS factors used in the calibration model include spectrum and, at the same time, concentration information. An important diagnostic tool is the PRESS (predicted residual error sum of squares) dependence on the number of PLS factors used for calibration, which makes it possible to estimate the optimum number of factors (Čurda et al. 2002; Jankovská and Šustová 2002). The PRESS behaviour is given in Fig. 2.

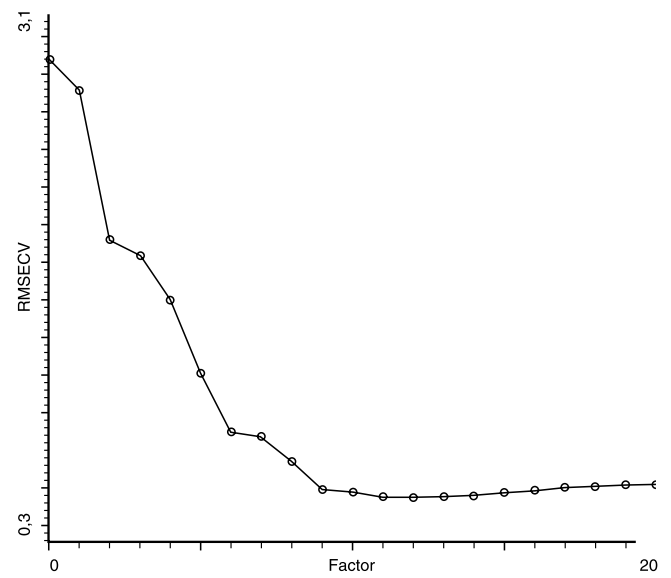

Fig. 2. Predicted residual error square sum (PRESS) for non-fatty solids

Correlation coefficients (R) and standard error of calibration values (SEC) were determined for a number of colostrum components, including total solids $(\mathrm{R}=0.986, \mathrm{SEC}$ $=0.919,8$ PLS factors, Fig. 3), fat $(\mathrm{R}=0.997$, SEC $=0.285,10$ PLS factors, Fig. 4), nonfatty solids $(\mathrm{R}=0.995, \mathrm{SEC}=0.451,8 \mathrm{PLS}$ factors, Fig. 5), lactose $(\mathrm{R}=0.934, \mathrm{SEC}=0.285$, 9 PLS factors, Fig. 6) and protein $(\mathrm{R}=0.999$, SEC $=0.149,12$ PLS factors, Fig. 7). For the cross-validation model, the same set of samples as for calibration was used. Validation is used to analyse the reliability of the calibration model and is expressed as the standard error of validation (SECV). In cross validation, $R$ and SECV values were computed for solids 


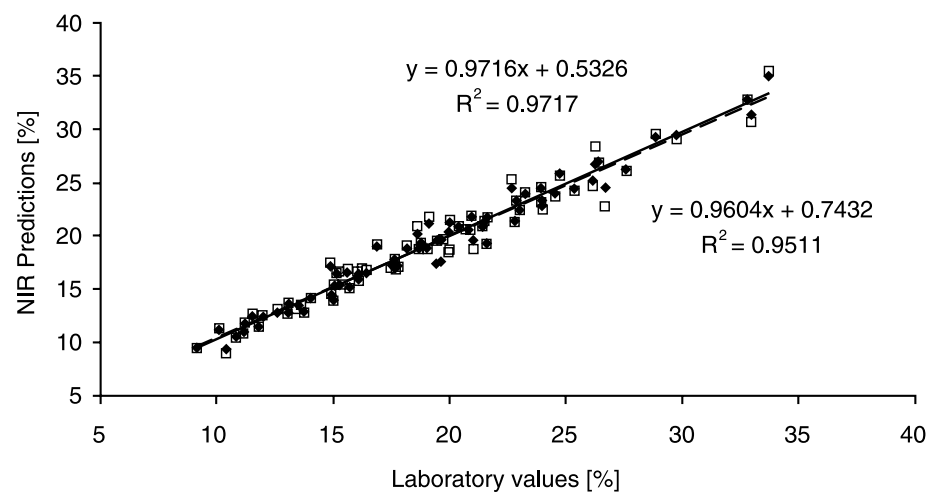

- Calibration $\square$ Cross-validation - Calibration - - Cross-validation

Fig. 3. Calibration and validation models for total solids

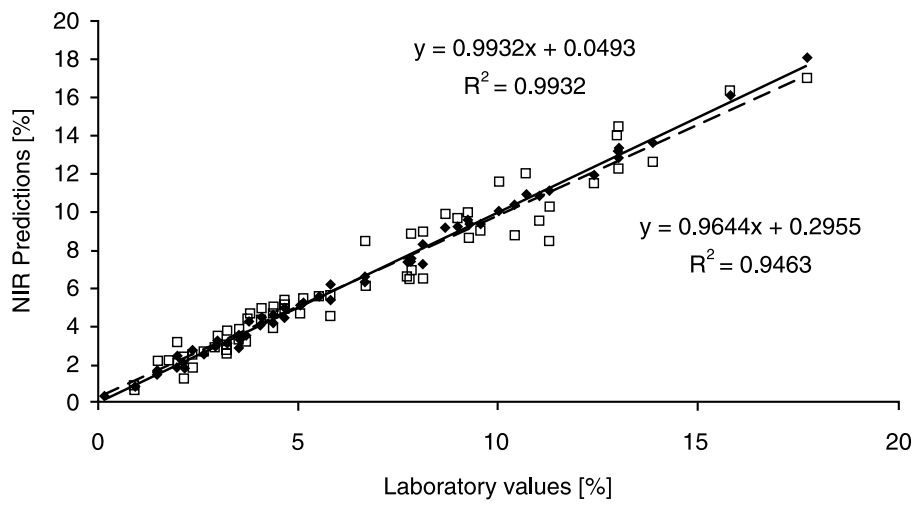

- Calibration 口 Cross-validation - Calibration - - Cross-validation

Fig. 4. Calibration and validation models for fat

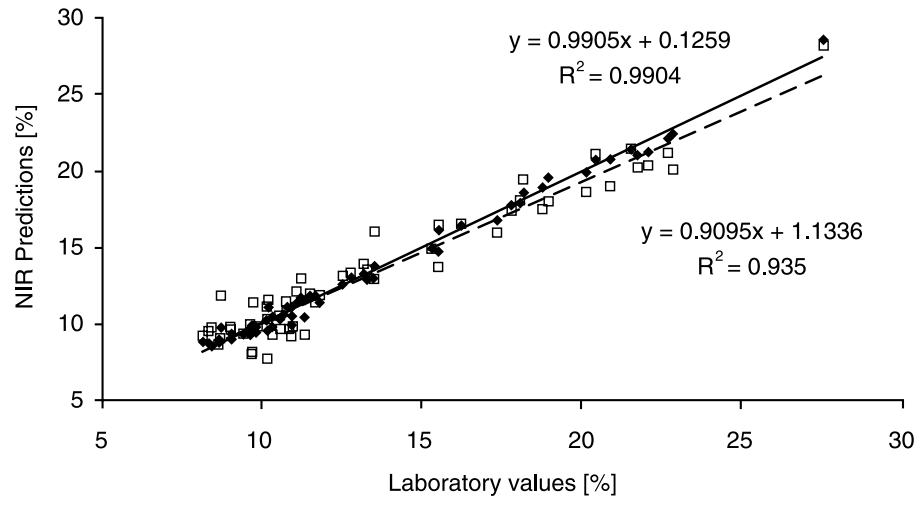

- Calibration a Cross-validation - Calibration - - Cross-validation

Fig. 5. Calibration and validation models for non-fatty solids 


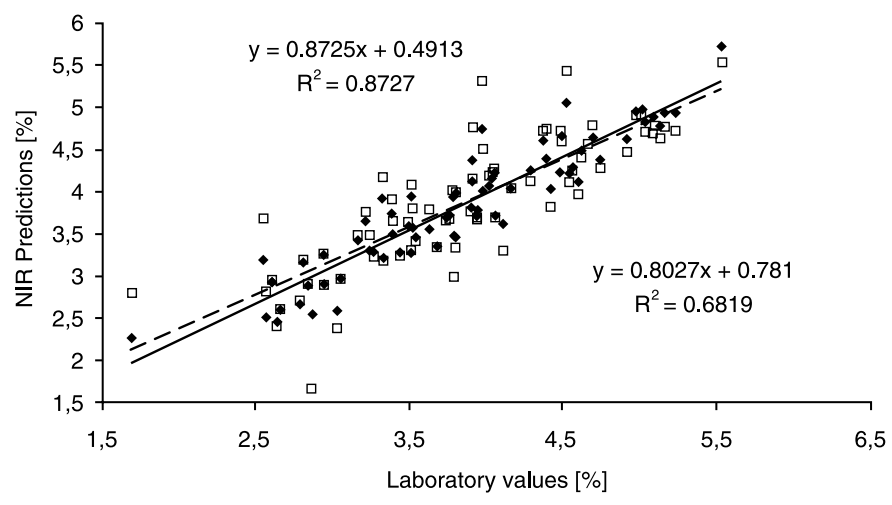

- Calibration $\square$ Cross-validation - Calibration - - Cross-validation

Fig. 6. Calibration and validation models for lactose

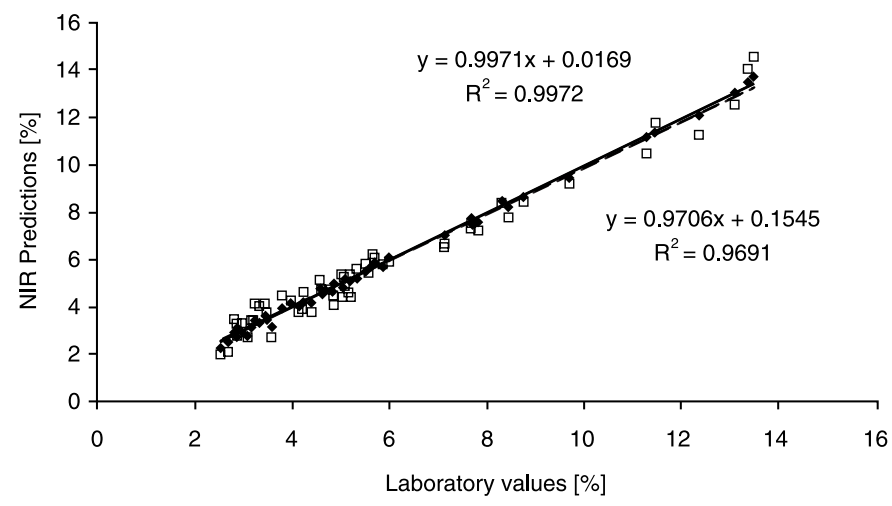

- Calibration $\square$ Cross-validation - Calibration - - Cross-validation

Fig. 7. Calibration and validation models for protein

$(\mathrm{R}=0.975, \mathrm{SECV}=1.210)$, fat $(\mathrm{R}=0.973, \mathrm{SECV}=0.885)$, non-fatty solids $(\mathrm{R}=0.967$, $\mathrm{SECV}=1.183)$, lactose $(\mathrm{R}=0.826, \mathrm{SECV}=0.464)$ and protein $(\mathrm{R}=0.984$, $\mathrm{SECV}=0.495)$. Calibration and cross-validation variables of colostrum are presented in Tables 1 and 2.

Another criterion for assessing calibration quality in NIR spectroscopy is the calibration coefficient of variance (CCV). CCV (expressed in percentages) is a ratio between the standard error and the average of laboratory values $\times 100$. In good-quality calibrations, $\mathrm{CCV}$ is $10 \%$ or less, the most reliable calibrations are those with CCV of $5 \%$ or less (Albanell et al. 1999). In the case of total solids, fat, non-fat solids and protein, CCV values are below $5 \%$. CCV exceeding 5\% was found in lactose (Table 1 ).

Similar results were obtained by Ts enkova et al. (1999) and Kukačková et al. (2000) in their analyses of non-homogenized cows' milk. Other authors also agree that NIR spectroscopy is suitable for analysis of various dairy products. Using NIR spectroscopy for the analysis of ewe milk, Albanell et al. (1999) reported correlation coefficients for protein, fat and solids of $0.92,0.97$ and 0.92 , respectively. Similar results were reported by Rodríguez-Otero and Hermida (1996) and Rodríguez-Otero et al. (1997b) for total solids, fat and proteins in fermented milk. 
Table 1. Calibration variables of colostrum

\begin{tabular}{|l|c|c|c|c|c|}
\hline Calibrated component & $\mathrm{R}$ & $\mathrm{SEC}$ & $\mathrm{CCV}[\%]$ & $\mathrm{a} \pm \mathrm{bx}_{\mathrm{i}}$ & $\mathrm{R}^{2}$ \\
\hline Total solids & 0.986 & 0.919 & 4.89 & $0.533+0.972$ & 0.972 \\
\hline Fat & 0.997 & 0.285 & 4.73 & $0.049+0.993$ & 0.993 \\
\hline Non-fatty solids & 0.995 & 0.451 & 3.42 & $0.126+0.991$ & 0.990 \\
\hline Lactose & 0.934 & 0.285 & 7.38 & $0.491+0.873$ & 0.873 \\
\hline Protein & 0.999 & 0.149 & 2.61 & $0.017+0.997$ & 0.997 \\
\hline
\end{tabular}

$\mathrm{R}$ - correlation coefficients; SEC - standard error of calibration values; CCV - calibration coefficient of variance; $\mathrm{a} \pm \mathrm{bx}_{\mathrm{i}}$ - variables of regression equation; $\mathrm{R}^{2}-$ value reliability

Table 2. Cross-validation variables of colostrum

\begin{tabular}{|l|c|c|c|c|}
\hline Calibrated component & $\mathrm{R}$ & $\mathrm{SECV}$ & $\mathrm{a} \pm \mathrm{bx}_{\mathrm{i}}$ & $\mathrm{R}^{2}$ \\
\hline Total solids & 0.975 & 1.210 & $0.743+0.960$ & 0.951 \\
\hline Fat & 0.973 & 0.885 & $0.296+0.964$ & 0.946 \\
\hline Non-fatty solids & 0.967 & 1.183 & $1.134+0.910$ & 0.935 \\
\hline Lactose & 0.826 & 0.464 & $0.781+0.803$ & 0.682 \\
\hline Protein & 0.984 & 0.495 & $0.155+0.971$ & 0.969 \\
\hline
\end{tabular}

$\mathrm{R}$ - correlation coefficients; $\mathrm{SECV}$ - standard error of validation; $\mathrm{a} \pm \mathrm{bx}_{\mathrm{i}}$ - variables of regression equation; $\mathrm{R}^{2}-$ value reliability

Results of reference values and values computed from NIR were statistically processed using a paired $t$-test in STAT plus software (Matoušková et al. 1992). No statistically significant differences $(p=0.05)$ were found between the reference value and the NIR-based computed value.

The results were evaluated on the basis of a correlation between reference and values computed from calibration equations, and on the basis of standard error of calibration and standard error of validation (SEC, SECV). The correlation coefficients approach the value of 1 , which is optimum for the use of the method. In combination with PLS, FT-NIR spectroscopy is a simple and rapid method for the determination of principal components of bovine colostrum. Very reliable models were obtained for total solids, fat, non-fatty solids and proteins and a reliable model was obtained for lactose. FT-NIR spectroscopy is a very useful method for a rapid analysis of bovine colostrum.

\section{Využití FT-NIR spektroskopie v analýze kravského mleziva}

Blízká infračervená spektroskopie s Fourierovou transformací (FT-NIR) byla, v kombinaci s metodou částečných nejmenších čtverců (PLS), použita pro stanovení obsahu sušiny, tuku, tukuprosté sušiny, laktózy a bílkovin v kravském mlezivu. Byla naměřena spektra u 90 vzorků v modu reflektance s transflektanční kyvetou ve spektrálním rozsahu 10000 - 4000 $\mathrm{cm}^{-1}$ se 100 scany. Statistické hodnoty korelačních koeficientů (R) a směrodatných odchylek kalibrace (SEC) získané kalibrací byly: pro sušinu $\mathrm{R}=0.986$ a $\mathrm{SEC}=0.919$, pro tuk $\mathrm{R}=0.997$ a $\mathrm{SEC}=0.285$, pro tukuprostou sušinu $\mathrm{R}=0.995$ a $\mathrm{SEC}=0.451$, pro laktózu $\mathrm{R}=0.934$ a $\mathrm{SEC}=0.285$ a pro bílkovinu $\mathrm{R}=0.999$ a $\mathrm{SEC}=0.149$. Vytvořené kalibrační modely byly ověřeny pomocí křížové validace. Ze studie vyplývá, že FT-NIR spektroskopii je možné použít pro stanovení složek kravského mleziva.

\section{Acknowledgements}

This study was supported by Grant 6215712402 of the Ministry of Education, Youth and Sports of the Czech Republic. 


\section{References}

ALBANELL E, CÁCERES P, CAJA G, MOLINA E, GARGOURI A 1999: Determination of fat, protein and total solids in ovine milk by near-infrared spectroscopy. J AOAC Int 82: 753-758

ALEXIEVA B, MARKOVA T, NIKOLOVA E 2004: Review. Bovine colostrum - the promising nutraceutical. Czech J Food Sci 22: 73-79

BÜNING-PFAUE H 2003: Analysis of water in food by near infrared spectroscopy. Food Chem 82: 107-115

CSN 570530 1995: Methods for testing of milk and milk products. Czech office for standards, metrology and testing, Praha, p. 100

ČSN ISO 6731 1997: Milk, cream and evaporated milk - Determination total solids content (Reference method). Czech standards institute, 1997, p.6

ČSN 570536 1999: Determination of milk content by infrared analyser. Czech standards institute, Praha.

ČURDA L, KUKAČKOVÁ O, NOVOTNÁ M 2002: Near-infrared spectroscopy and its application to milk and dairy products analysis. Chem Listy 96: $305-310$

ISENGARD HD 2001: Water content, one of the most important properties of food. Food Control 12: 395-400

JANKOVSKÁ R, ŠUSTOVÁ K 2002: Use of NIR spectroscopy to determination of yoghurt content. Mlékařské listy 71: 18-20

KUKAČKOVÁ O, ČURDA L, JINDŘICH J 2000: Multivariate calibration of raw cow milk using NIR spectroscopy. Czech J Food Sci 18: 1-4

MARNILA P, KORHONEN H 2003: Colostrum. In: Roginski, H (Ed) Encyclopedia of Dairy Sciences. Academic Press, London, pp. 473-478

MATOUŠKOVÁ O, CHALUPA J, CÍGLER M, HRUŠKA K 1992: STAT Plus - application manual. Veterinary Research Institute, Brno, p. 168

PAKKANEN R, AALTO J 1997: Review Paper. Growth factors and antimicrobial factors of bovine colostrum. Int Dairy Journal, 7: 285-297

RODRIGUEZ-OTERO JL, CENTENO J, HERMIDA M 1997b: Application of near infrared transflectance spectroscopy to the analysis of fermented milks. Milchwissenschaft, 52: 196-200

RODRÍGUEZ-OTERO JL, HERMIDA M 1996: Analysis of fermented milk products by near-infrared reflectance spectroscopy. J AOAC Int 79: 817-821

RODRÍGUEZ-OTERO JL, HERMIDA M, CENTENO J 1997a: Analysis of dairy products by near-infrared spectroscopy: A review. J Agric Food Chem 45: 2815-2819

ŠUSTOVÁ K, JANKOVSKÁ R 2002: Monitoring of casein content in milk by FT-NIR spectroscopy. Mlékařské listy 73: $24-25$

TSENKOVA R, ATANASSOVA S, TOYODA K, OZAKI Y, ITOH K, FEARN T 1999: Near-infrared spectroscopy for dairy management: measurement of unhomogenized milk composition. J Dairy Sci 82: 23442351 